\title{
Anti-Refugee Sentiment without Refugees: Human Rights Violations and Social Work in Post-Socialist Countries of Southeastern Europe in their Social Contexts
}

\author{
Darja Zaviršek ${ }^{1}$ (D) Barbara Rajgelj ${ }^{2}$
}

Published online: 29 December 2018

(C) The Author(s) 2018

\begin{abstract}
In the article, the authors pose a question: to what extent can we speak of social work practice in support of refugees in postsocialist Southeastern Europe given that in the region, which was part of the Balkans Humanitarian Corridor in 2015 and 2016, state-supported social work practice is very limited and very prescriptive at the same time? The vocal anti-refugee sentiment in Central and Southeastern Europe that accompanied the migrants can be said to stem from the nineteenth-century primordialism: the one-state, one-nation ideology that also was embedded in the very construction of post-socialist states after 1991. Consequently, refugees are seen as the ultimate danger to everything "ours," to women, men, and children of purportedly pure-blooded ethnonational origin, threatening "our" transgenerational sense of cultural and pseudobiological homogeneity. The rising post-socialist ethnonational primordialism, intertwined with conservative neopatriarchal ideologies, directly affects human rights observance and social work education and practice. The predominantly government-funded social workers generally are neither trained nor encouraged to work with refugees, while the popular and party politics of hatred is directed toward those who support refugees, social workers included. Anti-refugee sentiment, culturalization, and neopatriarchy are rationalized with arguments of fear and care; protecting the cultural and biological homogeneity of native residents leads to processes that turn care into violence, and ultimately into coercive care.
\end{abstract}

Keywords Anti-refugee sentiment · Southeastern Europe $\cdot$ Post-socialism $\cdot$ Social work $\cdot$ Coercive care

It took me some days to recover. After that, it was evident that war implies hatred directed against every difference, against Muslims in Belgrade, then against Roma, Albanians, lesbians - once they were Jews and Communists. And, that opposing war means coming out with the logic of supporting all social differences at once. One of the aims of war and pro-fascist ideology is not only separation of people of different nationalities, but the separation of people's own identities as well. That is how they can control us better.

Darja Zaviršek

Darja.zavirsek@fsd.uni-lj.si

Barbara Rajgelj

Barbara.rajgelj@fdv.uni-lj.si

1 Faculty of Social Work, University of Ljubljana, Ljubljana, Slovenia

2 Faculty of Social Sciences, University of Ljubljana, Ljubljana, Slovenia
Lepa Mladjenović ${ }^{1}$ 2001: 388

In the last twenty-five years (since when, in February 1991, a ship loaded with 26,000 Albanians entered the port of Brindisi) we have known that the great migration had begun. Two paths were possible at that point. Opening its borders, starting a global distribution of resources, investing its wealth in a long-lasting process of reception and integration of young people coming massively from the sea. This was the first path. The second was to reject, to dissuade, to make almost impossible the easy journey from Northern Africa to the coasts of Spain, Italy and Greece. Europeans have chosen the second way, and they are daily drowning uncountable children and women and men. Auschwitz on the beach. Franco "Bifo" Berardi 2017

\footnotetext{
${ }^{1}$ Lepa Mladjenović is a renowned human rights activist, one of the founding members of antimilitary women's movement Women in Black in Serbia, established in 1991. The quote refers to a homophobic attack she survived during the post-1991 war.
} 


\section{The Place and the Context}

In the countries of former Yugoslavia, people have been on the move, forcibly or voluntarily, escaping either from poverty or different forms of violence, throughout modern history. ${ }^{2}$ The former Yugoslav socialist republics have a long emigration as well as immigration history. During the first half of the twentieth century, people from today's Slovenia emigrated due to economic scarcity and poor work opportunities, whereas substantial economic immigration of people from other parts of Yugoslavia, notably Bosnia and Herzegovina, occurred during socialism in the 1960s. After independence in 1991, Slovenia experienced a mass influx of refugees ${ }^{3}$ and migrants twice: During the 1990s war in Bosnia and Herzegovina, 60,000 refugees found shelter in mostly private accommodations, with their relatives. The second large refugee crisis occurred between August 2015 and March 2016 during the Europe-wide migration of more than half a million refugees from the Middle East. Slovenia was on their way to Western and Northern Europe. They reached Slovenia predominantly through the so-called Balkans Humanitarian Corridor, from Turkey and Greece through Macedonia, Hungary, Bulgaria, Serbia, and Croatia to Slovenia.

This article offers a view of the violations of the human rights of refugees and undocumented migrants that occurred during the time of the Balkans Humanitarian Corridor and after its shutdown. It shows how rising post-socialist ethnic and national primordialism, closely intertwined with conservative neopatriarchal ideologies, directly affects human rights observance as well as social work education and practice. In the "Social Work Practice" section, most examples are from Slovenia where the vast majority of research took place. In order to prove their cause, the authors use a variety of research methods including ethnographic observation and diaries; interviews and personal experiences; and media analysis and the analysis of different international documents. The research has no particular time frame and was not funded by any research agencies or donors; it is an on-going voluntary work which is part of the academic "labor of love" (Alvarez 2017).

\footnotetext{
$\overline{2}$ The ideological legacy pertaining to ethnicity, religious groups, and nationalism in this region springs from large empires such as the Habsburg monarchy (until 1918) and the Ottoman empire (until 1922), and the turbulent post-World War I and World War II states: the State of Slovenes, Croats, and Serbs (from October to December 1918), Kingdom of Serbs, Croats, and Slovenians (1918-1929), and finally the Socialist Federative Republic of Yugoslavia (1945-1991).

${ }^{3}$ The authors of this article use the words migrants, refugees, asylum seekers, and people on the move interchangeably. The categories that grant different rights to a person according to a different category are often arbitrary; it is often impossible to draw a line among these statuses as they fragment the global society. These terms will sometimes define the legal statuses of people, and at other times define the situation of people moving from one country to another for different reasons.
}

The refugees of 2015-2016 were fleeing the warring areas of the Middle East following a path that was reasonably free of surveillance. ${ }^{4}$ The "new images of exodus," to recall Mbembe (2017, p.29), involved 7800 persons crossing the southeastern border of Slovenia daily. Quickly enough, several processes of militarization and securitization took place in the entire region. One of the most dramatic demonstrations of state violence was the erection of razor-wire fences on the borders to prevent refugees from entering illegally. Slovenia placed the fences along $200 \mathrm{~km}$ of its borders, including the entire border with Croatia. The institutional responses to the challenge of dealing with the refugees were increasingly bureaucratized at the borders, in the buffer zones, in asylum and detention centers, and at the hotspots, resettlement centers, and refugee camps to prevent the refugees' movement.

Once the Balkans Corridor began to close, criminalizing and dehumanizing the migrants became the major preoccupation of the state authorities, especially on the first contact at the borders. In response, the majority of Western governments stepped up policing the migrant people, legislatively and in concrete handling (Hathaway 2016; Zaviršek 2017). The Hungarian, Macedonian, Serbian, Croatian, and Slovenian governments, in line with push-back politics, presently often return persons who cross the border illegally, including those who seek asylum. In 2017, Slovenia passed an amendment to the Foreigners Act that allows for emergency measures to be taken in the event of extraordinary circumstances; in the situation of so-called changed circumstances, the government reserves the right to refuse entry to the country to a foreign person and deny their right to apply for international protection. The amendment contravenes the Geneva Convention (1949) and the Dublin Regulation of the European Union (EU) and would mandate that Slovenia formally withdrew from the Convention should the Constitutional Court confirm the amendment. ${ }^{5}$ According to the Slovenian Constitution, the right to enter the country can be restricted only under very specific conditions, such as an emergency that brings the existence of the state under threat (Constitution of the Republic of Slovenia 1991, Art. 92). The proposed legislation also suggests that the neighboring countries are safe in terms of access to a fair asylum procedure; however, most refugees who enter Slovenia come from Hungary and Croatia, the two countries that are known for their push-back policies and keep returning the refugees to Serbia or Macedonia (HRW Serbia 2015). International reports documented how the Croatian police violently forced the asylum seekers back to Serbia, denying them the opportunity to lodge

\footnotetext{
${ }^{4}$ Thus the Macedonian government for instance decided that a person who entered the country in $2015 \mathrm{had} 72 \mathrm{~h}$ to travel through its territory in order to leave it without legal restrictions.

${ }^{5}$ As of August 2018, the proposed amendment was still under the review by the Constitutional Court.
} 
claims for protection and complaints of violence suffered in some cases (HRW Croatia 2017). ${ }^{6}$ The international NGO "Moving Europe" documented violent push-backs of undocumented migrants from Croatia to Serbia in several instances during 2016. ${ }^{7}$ In 2012, the UN Office of the High Commissioner for Refugees defined Serbia as a country that should not be considered a safe third country for asylum seekers because of its lack of fair and efficient asylum procedures; consequently, the EU states should not return asylum seekers to Serbia. This same conclusion was reaffirmed in 2016 and 2017 (HRW Croatia 2017; HRW Serbia/Kosovo 2017). ${ }^{8}$

As the people on the move strive to reach their desired destinations, only very few remain in Southeastern Europe, and even fewer decide to apply for international protection. In Slovenia, there had been approximately 300 applicants in 2015, 1308 in 2016, and 1400 in 2017. In 2016, only 170 were granted asylum after an average lag time of 110 days. In January 2017, there were only 300 persons in the country awaiting a decision regarding the asylum; 80 waited longer than 6 months. The delays were obviously a strategy to discourage people from applying for asylum and to encourage them to leave the country as soon as an opportunity presented itself. Croatia, too, served mostly as a transit country, with few people applying for international protection: there were approximately 211 applicants in 2015 and 2235 in 2016. Comparable circumstances are reported in Bosnia and Herzegovina in 2018: people stay for a few nights to avoid entering Hungary and to shorten their way through Croatia before reaching one of the Western countries.

After the closure of the Balkans Humanitarian Corridor, more than 7000 refugees and migrants, among them approximately 1000 unaccompanied children, remained in the buffer zone in Serbia that thus became "a prison country" (Lipovec Čebron and Zorn 2016). The authorities provide the immigrants and refugees with accommodation, food, and other types of support, but 18 asylum and reception centers across Serbia operate beyond capacity, resulting in poor living conditions. The treatment, support, education, and security of unaccompanied children is insufficient. Criminal activities such as smuggling have developed into a complex social issue (Boček 2017). Of 574 asylum applications submitted in 2016, mostly on the part of Afghans, Iraqis, and Syrians, the Serbian government granted asylum to only 19 persons, whereas 23 got subsidiary protection (HRW Croatia 2017). From January to 31 October 2017 the Asylum Office granted refugee status in three cases and subsidiary protection in 10 cases (Belgrade

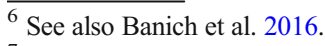

${ }^{7}$ Narrative-based evidence produced by social work volunteers (personal notes, DZ, April 2018) say that violent pushbacks by the Croatian police increased, and that the people face more violent interventions and suffer injuries during escape attempts. One such common injury is broken ankles. In August 2018 the formal sources reported 10 deaths by persons who wanted to cross the Croatian border illegally and the use of firearms by Croatian police at the border (Matić 2018).

${ }^{8}$ See also UN High Commissioner for refugees 2012, 2016.
}

Center for Human Rights 2017). To avoid the EURODAC fingerprinting and push-backs, hundreds of migrant people are sheltered in abandoned factories during the day and spend the nights in the so-called jungle settlement in a forest. The temperatures may be well below zero, and the area is supervised by police in riot gear (personal communication with volunteers, March 2018).

Despite the small number of people granted international protection in the countries of post-socialist Southeastern Europe, very strong anti-refugee sentiments persist. Several local and national media are inciting racist and xenophobic responses of the public: they use the same primordialist slogans that were used against Roma people and LGBTQI communities in the past, e.g., "No camps, no jobs, no money, no food for illegal refugees!" and "Islamists not welcome!"9 In line with the historical "antisemitism without Jews," one could argue that there is a persistent anti-refugee sentiment, primarily Islamophobic, even if there are very few refugees. Of special concern is the fact that these sentiments are shared by the masses and the official state politics. The EU guidelines and regulations hardly matter anymore, even as the state authority carries a little weight in the periphery: in one part of Slovenia for instance, municipal authorities held an emergency meeting in 2017 in protest of the state decision to accommodate of a few refugees in the social fund flats in Maribor, even as the government acted in compliance with the EU resettlement agreement. ${ }^{10}$

In September 2015, a national survey in Bulgaria showed that $63 \%$ of the citizens believed that the refugees were a danger to their country, and the majority of respondents (82\%) supported fortifying the border fence (Stoyanova Packova 2016). Protests against refugees were organized all over the county, especially in rural areas with high unemployment and social insecurity, and in places where there were no refugees. Anti-immigrant protests unite people of different professional, political, ethnic, and class backgrounds.

\section{The Blank Spots of the Mainstream Social Work in Southeast Europe}

Although governments and mainstream social workers in Southeastern Europe need to accommodate a relatively low number of refugees including unaccompanied children (with Greece as the exception), they repeatedly claim that the refugee crisis caught them unprepared. This goes to prove that the modus operandi of the political systems and their subsystems including social work in the region is based in the reification

\footnotetext{
${ }^{9}$ Used in the demonstrations outside the Slovenian parliament building, 27 February 2016.

${ }^{10}$ According to the EU agreement of resettlement, the Slovenian government agreed to receive 567 asylum seekers from Italy and Greece by the end of 2017; not all of the "quota refugees" arrived as yet.
} 
of refugees instead of focusing on how different ethnicities can live together in one territory, in what Schwenken (2018) calls today's "migration-societies."

In social work, it has long been recognized that alliances between professional workers and service users, although not free of power inequalities, are part of human rights practice. But neither mainstream social workers nor most of the global population agrees that the migration societies are part of the globalized world, even though the latter is not free from postcolonial power struggles between the core countries and those of the global periphery. Wars, ecological disasters, and economic shortages in one part of the world inevitably affect others; human disasters in the global South are co-created by the global North; today's refugees and economic migrants are produced in proxy wars that the global West wages politically and through the supply of weapons. The West collaborates with a number of authoritarian regimes, extremist groups, and military formations in different parts of the world to generate profit for itself, which causes more instability and political conflicts and consequently, people on the move (Balibar 2004, 2015). Lack of understanding of these interlinked processes is evident in social work curricula and practice, especially as they relate to undocumented migrants and refugees in Southeastern Europe. Social workers' identity is mainly tied to "working with families and children" (meaning the majority families) while political social work is very nearly nonexistent.

State-supported social work practice with migrants is very limited: the major asylum home in Slovenia, for instance, employed a single social worker for 200 residents in April 2018. The refugees can be said to exist through their nonexistence, social invisibility, and dehumanization. This situation requires that we ask: Can one speak about social work with refugees in post-socialist Southeastern Europe at all?

The problem is not that of homogenously underdeveloped post-authoritarian societies that fail to grasp diversity and human rights, or the old fashion "cold war" image of the post-socialist countries of Eastern Europe. Quite the contrary: The region is widely diverse and politically polarized. Many individuals, groups, and organizations clearly recognize the interrelations in conflicting world developments and actively fight for human rights and justice. Diverse movements struggle for women's rights; against the growing precariousness of workers' situations; for the rights of children; against neoliberal policies and corporate dominance; against privatization of regional water resources; against wars and NATO-led militarization; for human rights of LGBTQI persons, and so forth. But there are also masses of centrist opportunistic bystanders and a vocal, conservative portion of the population, politically increasingly well represented, who believe that the mythical, ethnically pure national communities are the natural order of things. They perceive nations as harmonious communities of blood-related generations of people who share a genetic origin, history, tradition, language, and culture. They view such primordial ethnic communities as endangered by every and any kind of "other".

We maintain in this article that the very vocal anti-refugee sentiment of today is built on the nineteenth-century primordialism, the one state-one nation ideology that was also embedded into post-socialist states after 1991 as a form of social creationism (Šumi and Janko Spreizer 2011; Šumi 2012). Essentially, the end of totalitarian regimes, the introduction of multiparty political systems, and the turn to capitalism were seen as the affirmation of the primordial ethnic nation community. Consequently, refugees are seen by the majority of the resident population as the ultimate danger to everything "ours": to the women, men, and children of pureblooded national origin and their transgenerational sense of cultural and pseudobiological homogeneity (Anderson 1995; Geertz 1963; Gellner 1983; Murat 2009). The socialism era (proletarian) internationalism is widely seen as a primary offense of the socialist regimes against such ethnonational homogeneity.

The ideals of democracy, human rights, and equalitythat is, building an open society, to echo the intellectual impact of the philanthropist George Soros in the regionhave been countered in the last 2 decades by an increasingly vocal conservative public, notably through a political discourse in which sexism, antisemitism, racism, and hatred of refugees are coalesce into an ideology. In this imagery, women are no longer equal and emancipated humans as they were, at least nominally, during socialism, but are instead primarily the mothers of "our children". ${ }^{11}$ Advocacy for equality of people of non-normative sexuality is seen as a proof of a leftist decadence. The Roma minority, quite populous in many post-socialist countries, is routinely racialized and ethnicized, whereas refugees and migrants are widely believed to be a threat to the Christianity and European civilization. The politics of hatred flourishes, having gained legitimacy also in the spheres of parliamentary and state politics.

\footnotetext{
${ }^{11}$ A blatant example of a post-socialist antidemocratic politician provocateur for the neopatriarchy who tries to influence the public views is the former Polish MEP Janusz Korwin Mikke who notched up his hostile statements in the European Parliament by sporting the Nazi salute in 2015, comparing migrant people in Europe to »excrement « in 2016, and opined that women should be paid less »because they are smaller, weaker, and less intelligent than men«. He also maintained, in 2017, that too many women work outside the home and have therefore too few children (Cf.: Euronews, 2. March 2017, European Parliament, Retrieved from https://www.youtube.com/watch?v=UuxToQvHh0; Euronews, 15. November 2017; European Parliament; Retrieved from https://www.youtube.com/watch?v=UuxT-oQvHh0; BBC News: EU court overturns parliament's punishment of Polish MEP for sexism, 31. 5. 2018. Retrieved from https://www.bbc.com/news/world-europe-44319826.
} 


\section{The Fertile Ground for Anti-Refugee Sentiment in Post-Socialist States}

\section{Ethnic Primordialism}

Post-World War II European socialism, in view of the genocide perpetrated during the war and the global process of decolonization following WWII, found different ways of coping with an ethnic difference. Although in Yugoslavia, for instance, the doctrine of nations and nationalities who were supposed to live in brotherhood and unity sought to establish a brand of emancipatory thinking, the very different legacies of the Austro-Hungarian and Ottoman empires respectively were averse to the effort that was itself based in certain categorical beliefs. The primordial beliefs in ethnic homogeneity were certainly not overcome either in legal encoding, political thinking, or folk understandings. The socialist understanding of Roma, Sinti, and Ashkali who live in the region, similarly to what Law (2012) showed for the ethnic minorities in the former Soviet Union, shifted from notions of biological inferiority to those of a cultural deficiency: they could overcome their historical backwardness only with assimilation, accomplished by wiping out the Romani language, family names, and identity. ${ }^{12}$ And as is very clear from a body of studies of antisemitism, the latter was never extinguished.

In early post-socialism, two processes converged: historical revisionism, especially as concerns World War II and its immediate aftermath; and the widespread idea that the time to affirm and enact the ideal of true ethnic homogeneity is once "real" democracy is instituted. In Slovenia, for instance, this belief was legally encoded in the 1992 constitution by developing into a full constitutional category the concept of autochthony, which was present in basic contours already in the 1973 socialist constitutional amendments, and was inspired mainly by the legal instruments of the decolonization process (Šumi and Janko Spreizer 2011). At the time of Slovenian independence, there was a pronounced anti-Serbian sentiment, a revolt against socialist Yugoslav principles of ethnic coexistence, and the perceived need to homogenize the population of Slovenia. The transitional DEMOS government stripped approximately 25,000 people, Slovenian residents and Yugoslav citizens who originated in other ex-Yugoslav republics, of their resident status once they failed to apply for the new Slovenian citizenship. The statuses of permanent resident and citizen were conflated in a decidedly

\footnotetext{
12 In a social work study, an older Roma from Slovenia who was asked about Roma culture responded, "I do not remember anything particular from my family and my youth; we did not have any particular Roma culture. The only difference I always noticed was that we were poorer than Slovenians" (personal communication with Špela Urh 2011).
}

illegal manner. These so-called Erased were essentially treated as illegal migrants vulnerable to detention and deportation (Zorn 2005, 2009). ${ }^{13}$ The quiet elimination of legal statuses and social rights was not just a caesura in a new democratic state, but a constitutive part of it. The history of injustices and deprivations of the Erased, including those who suffered at the hands of the welfare services, is still not a part of the master narrative of the Slovenian post-socialist history.

\section{Neo-Patriarchy and Coercive Care}

Ethnic primordialism is also linked to human rights violations in other post-socialist former Yugoslav countries. Serbia is guilty of certain war crimes and a series of serious human rights and humanitarian law violations during the 1990s wars in Bosnia and Kosovo. Ethnic primordialism also consistently goes hand in glove with the processes of neopatriarchy. Zaviršek (2018) defines neopatriarchy as the continuation of patriarchy in new circumstances of global neoliberalism wherein women are not seen as dependent and weak but accused to be too emancipated and autonomous. As such, they are dangerous for both the pauperized male losers of globalization and for the new elite of male economic winners; both want to discipline women for different reasons, and in order to achieve this goal, use the alliances, as shown by Fraser (2007), with conservative religious authorities and extremist authoritarian groups. As so often in history, women are seen as scapegoats of today's neoliberal economic crises and societal anomy.

In post-socialist countries, there is a lack of a legal and institutional framework for the fight against discriminationfor example, gender equality - and legal protection of people of nonnormative sexual orientation (Muižnieks 2015). The processes of culturalization in Southeastern Europe often end in coercive care (Zaviršek 2018). Social workers, educators, and medical doctors in the region regularly encourage Roma parents to send their children to special schools as they see them as less intelligent and prone to mental and intellectual disabilities. The EU monitoring and the advocacy program of the Open Society Institute (2007) showed that in post-socialist countries of Southeastern Europe, Roma children are either

\footnotetext{
${ }^{13}$ In 2002, the people affected organized in a civil association called the Erased and launched a political campaign for their rights. Moral and material compensations came late. After more than 20 years, the Slovenian Constitutional Court in 1999 and 2003 and the European Court of Human Rights in 2012 decided that the erasure was a violation of human rights and ordered financial compensation to individuals. A handful of social workers were actively involved in the struggle for their rights. It is worth adding that the restoration of justice was deferred by both the indecisiveness of the Slovenian neoliberal left and the primordial ethnic nationalism of the right-wing parties. In 2004, the latter demanded a referendum against the enforcement of a reparative law that the Constitutional Court mandated. Only $31.45 \%$ of the eligible voters participated in the referendum, but no less than $94.68 \%$ voted against the restoration of justice (Zorn 2009).
} 
overrepresented in special schools for children with intellectual disabilities (especially in Bulgaria, Macedonia, and Slovenia) or segregated into Roma-only classes (Croatia). The internalized intentional and unintentional racism of the different professionals who "care" for the children produce more violence against Roma ethnic minority communities; the children are pathologized and ethnicized, and the diagnosis of intellectual disability is expected to "protect" children from a competitive environment and from economic disadvantages (Humljan Urh 2014; Urh 2011; Zaviršek 2001). The racialization of Roma continues today, and disability labeling and spatial segregation of children in primary education, are the major symptoms. In Slovenia, the Association of the Centers of Social Work organized the first symposium on social work with Roma people only in 2015; most of the speakers from social work institutions started their presentations with the assertion that Roma came from India, an expression of racism wrapped in myth that was employed also by the Constitutional Court in one of its legal opinions (Šumi and Janko Spreizer, 2011). With the arrival of refugees, racism against Roma did not disappear but was transposed from the internal to external Other; people claim that "there are already enough foreigners," meaning, primarily, the Slovenian Roma (ethnographic notes, DZ, 3 April 2018).

\section{When Care Turns into Violence: the Link between Anti-Islamism and Christian Neo-Conservatism}

The increased impact of the majority of faith religious structures in European post-socialism fertilized the neoconservative movements to marginalize and pathologize the uncomfortably visible LGBTQI people and their struggle for equality. Describing the situation in Croatia, Hodžić and Stulhofer (2017) assert that the political and social influence of the Croatian Catholic Church "has steadily increased, primarily due to its pivotal role in collective identity building and its staunch anti-communism, which resonated well with the conservative politics of the ruling party" (p. 59). The Croat Voice of Parents for Children, founded in 2006, promotes the parents' right to educate their children in accord with the "Croatian value system"; in 2012, they organized against the health education program in schools, claiming that the inclusion of themes such as sexual diversity and reproductive rights is tantamount to sexualizing children and promoting homosexuality. The civil movement Vigilare, founded in 2012, fights the "endangering of the Croatian cultural tradition," by opposing the LGBTQI agenda and abortion. A civil initiative called I Was an Embryo, Too, was established in reaction to the Bill on Medically Assisted Reproduction (2012) that allowed frozen storage of embryos and artificial insemination for single women (Hodžić and Štulhofer 2017, p. 62). In
Slovenia, the 2001 referendum on reproductive rights of single women denied them access to medical reproductive technology. Roughly, a third of the voting body participated, demonstrably activated by the ardent propaganda of the Slovenian Catholic Church. The legislation was challenged in the Constitutional Court three times but was dismissed on procedural grounds each time (Muižnieks 2017). In the last few years, the antiabortion agenda has been more prominent in Slovenia, with the appearance of nongovernmental organizations (NGOs) supported by religious organizations and the political parties that prioritize the antiabortionist agenda. These consolidated into the coalition, United Right, for the June 2018 general elections. Since 2015, prayers for unborn children are regularly staged in front of the Ljubljana maternity hospital. In the 2017 presidential elections campaign, a woman right-wing candidate insisted that children conceived in rape should be born.

Equal treatment of women and people of nonnormative sexual orientation remains a human rights issue in all the countries of Southeastern Europe (Slootmaeckers et al. 2016). Amendments to the Serbian constitution of 2006 (Constitution of the Republic of Serbia 2006, Art. 62) and the Croatian constitution of 2013 (Constitution of the Republic of Croatia 1990, Art. 62) explicitly define marriage as the relationship between a man and a woman. In Serbia, LGBTQI activists are subject to threats, attacks, and hate speech generated by the leaders of extreme right movements, nationalist political parties, and representatives of the Orthodox Church. ${ }^{14}$ During the gay pride parade in Belgrade in 2001, sports fans, ultranationalist groups, and nationalist party sympathizers violently attacked the parade's participants, chanting "Serbia is not a homosexual country," and "Serbia for Serbians, not for homosexuals" (Simo 2001). ${ }^{15}$

The situation is similar in Bulgaria where the constitution defines marriage as the union of a man and a woman and effectively prohibits the legalization of same-sex marriage (Constitution of the Republic of Bulgaria 1991, Art. 46/1); the legislation does not recognize any type of same-sex union. In January 2017, an "anti-propaganda" law was proposed by the far right, but was rejected; the bill was reintroduced after the elections in October 2017 (ILGA-Europe 2015, p. 52). In June 2017, a group called National Resistance, which pledges to protect Bulgaria from "foreign ideologies" such as parliamentary democracy, moral decay including "strongly propagandized sodomy," and the "parasitism of minorities," registered a

\footnotetext{
${ }^{14}$ After the singer Conchita Wurst won the Eurovision Song Contest in 2014, the head of the Serbian Orthodox Church, patriarch Irinej, declared that the severe regional floods, which killed 50 people, were the "divine punishment for homosexuals' vices" (ILGA-Europe 2015, p. 143).

15 The gay pride parades from 2014 to 2017 in Belgrade were conducted without serious incidents but guarded by thousands of police officers. The last one was attended also by Ana Brnabić, the first openly gay prime minster in any Southeastern European country (RFE 2017).
} 
counter-demonstration at the planned location of Sofia Gay Pride. In a public video stream, the leader of the organization urged the public to bring "brooms and shovels with wooden handles" to "rid Sofia of garbage" (Knight 2017). There are no reports of organized resistance to these events by social workers.

An identical structure of hatred, based on the idea of the imagined primordial community, the "Ours," the Christians, and the civilized, was mobilized after 2015 in relation to refugees and migrants. The myth of Europe as synonymous with Christianity, democracy, and capitalism, which was persuasively deconstructed by Amin (2009/1988), became part of everyday ideation and discourse. The above examples show that many people living under Southeastern European postsocialism have been living in parallel worlds: Although some defined global neoliberalism as democratization, others experienced the period as a time of infinite wars. Consequently, refugees, too, often say that each crossing of the national border has reminded them of the war they fled; refugee deaths occur not just in the sea but also in small rivers along the borders (in the river Kolpa at the Croatian-Slovenia border, for example). Italian critical thinker Berardi (2017) referred to this when he spoke about "Auschwitz on the beach."

In these circumstances, the predominantly governmentfunded social workers are neither trained nor encouraged to work with the refugees. Often, the politics of hatred is directed toward those who support refugees: the local people, a handful of independent social workers, social work students, and workers in the NGOs. In March 2018, a Slovenian right-wing television station and a Christian fundamentalist online magazine attempted to stir up public outrage against a group of postgraduate social work students enrolled in the only social work-study program in the country (the Faculty of Social Work, University of Ljubljana) after their return from fieldwork in Serbia, where they worked with refugees living in a "jungle" settlement. The vitriolic attacks were wrapped in a language of care, expressing concern for "our girls" (Donko 2018):

See what the FSD does with their students! [...] They sent the female students to entertain migrants [...]. Does the Faculty of Social Work not find any other example of human suffering, a homeless, an elderly or abandoned person, along with whom the future social workers could develop empathy? According to our source, the empathy of the future social workers to "young, goodlooking men with white teeth" went so far that during their stay some of them felt in love with migrant men in the squat and now seek the ways to return.

The response that the author counted on was fast and copious. Scores of anonymous commentators in the comments section hardened the author's violence masked as coercive care. There was a torrent of hatred for social work students and social work educators; there were calls for sexually violating the "Muslim whores," "killing social work professors," and "closing down the faculty." The hate speech did not end with spreading antirefugee propaganda; it targeted human rights values promoted by critical social work. The social work department was tagged as a "breeding place of leftists, homosexuals, and feminists, who prefer to help the Muslim men rather than the Slovenian poor."

How can one function as an active advocate in the field of social work with refugees in such a climate, and what is the impact of such violent discourse? In the aftermath of the above incident, which expanded to weekly installments of "reports" for more than a month, social work teachers involved in the fieldwork deemed it a priority to teach nonviolent resistance and political social work to students and to deconstruct the hate speech, xenophobia, anti-Islamism, and neo-patriarchy in the media. The university reported the incident to police, and the school organized a round table discussion to reflect on the events. Left-wing media chimed in and published the statements of the affected students and their mentor with extensive analysis (Košir 2018). Nevertheless, fear and even mutual mistrust spread among the students: "I'm afraid to be attacked by the local people in my village when they read what was written about us"; "I will not share my feelings during the seminars anymore; for me the university is not a safe place anymore" (personal notes, 15 March 2018). Many students experienced the media attacks as a state of war and identified with the refugees who face similar violent racism when they arrived in Europe.

These events illustrate how violence and the impressions of the state of war in the public sphere, also as an extension of actual ongoing wars, became an essential part of today's everyday experience of democracy. Mbembe (2017) rightly emphasized that today's wars are seen as part of democracy, politics, and culture, a necessity and normal occurrence. The wars are perceived as the pharmacon, the medicine that heals as well as poisons; the externalized "just wars" and the inland "wars on terror," the "wars" against difference, and the "preventative wars." Feldman (2015) stressed that today's wars no longer engage entire national populations and territories; rather, they are mosaic wars experienced by some but not by others. The survivors among the Erased in Slovenia of the 1990s experienced their ordeal as a state of war with an everyday struggle for health care, social support, and economic means, whereas the majority of the population lived in a flourishing post-socialist democracy.

The anti-refugee sentiment, culturalization, and neopatriarchy are today rationalized by the discourses of fear and care; care for the "ours," women, young children, and the nation. The religious fundamentalist media use the ideology of care for "our young women," who need to be protected from "young violent Muslim men," as well as from critical social work that promotes diversity, equality, and human rights. The forms of violence that hide behind the discourse of care are difficult to recognize and attract diverse people (Zaviršek 2018). Violent care and the discourse of fear reproduce anti- 
refugee sentiments; they manifest themselves in different social arenas, from politics to professionals to religious representatives. In Slovenia, an ex-bishop of Ljubljana skillfully combined fear with violent care, referring to Pope Francis as follows: "We in Europe, who have a sense of identity, feel threatened; an Argentinian probably lacks this feeling. Because we are threatened, we are sensitive to some issues."16

\section{Social Work Practice}

While the Balkans Humanitarian Corridor was active, social work interventions were predominantly ad hoc in all countries involved. Apart from administrative procedures, state-paid social workers were not involved in direct work with refugees; in some cases, their activities amounted to what Bradol (2004) called "armed humanitarianism." Some social work interventions took place at the national borders and in the refugee camps and hotspots during the periods of the heaviest influx of people on the move, while the integration programs were offered primarily by NGOs. In most Southeastern European countries, social workers helped people within the organized activities of the Red Cross, UNHCR, and other humanitarian organizations. Certain very basic social work methods, providing practical support, cultural translation, emotional comfort, and challenging people's dehumanization were often perceived as adverse to the interests of the state. Thus, practicing social work at the borders, in the asylum camps, and in refugee centers became politicized and was considered subversive when social work activists disobeyed the orders of the security personnel regarding talking to the refugees and declined to wear gloves and protective masks (Zaviršek 2017).

Although social work with refugees is provided mostly by state-funded NGOs and volunteers, a broader picture of social work practice today includes several types. Administrative social work by the governmental centers of social work are primarily responsible for the children ${ }^{17}$; finding the legal guardian for special circumstances (skrbnik za posebni primer) and a legal guardian (zakoniti zastopnik) of unaccompanied children and the accommodation for the minors. In cases of unaccompanied children, the police at the border have to inform the centers of social work, and a social worker is obliged to meet the child and to assign a legal guardian for special circumstances to the child. Due to other obligations, social workers sometimes refuse to come to see the child at the border, so that only the legal guardian for special circumstances meets the child. A more inclusive social work practice

\footnotetext{
$\overline{16}$ Interview with Anton Stres, retired bishop of Ljubljana, currently director of the Catholic Institute of Slovenia, an incipient institution to a prospective Catholic university (Gregorc 2018).

${ }^{17}$ The centers of social work were established in the 1960s and remain the basic social welfare institutions across all parts of former Yugoslavia (Hessle and Zaviršek 2005).
}

is provided by NGOs, such as establishing integration houses and day-to-day support for refugees, as well as doing advocacy and political social work with governmental organizations; person-centered social work is provided by social workers and other professionals primarily on behalf of unaccompanied children.

Adults alone and with children who cross the Slovenian border illegally are sent to the detention center called the Center for Foreigners (Center za tujce) located in the small town of Postojna. Unaccompanied children are placed either to the detention center or directly to the asylum home (especially if the child expresses the wish to continue the journey and refuses to apply for the international protection). The detention center lacks psychosocial support or other treatment for children, and sending the child to such a facility is against Article 37 of the UNCRC. ${ }^{18}$ When the child is accommodated in one of the abovementioned facilities, the social worker appoints a legal guardian to the unaccompanied child; these are persons who get through a short-term training for unaccompanied minors and are from different backgrounds, rarely social workers.

Nevertheless, children who arrive with parents and relatives are not separated from them unlike the recent practice in some countries (Gessen 2018; Walsh 2018). The refugees receive emergency health care if wounded and are screened for infectious diseases. In the asylum home, social work activities are at a bare minimum and chiefly administrative in nature, such as providing information about rules and procedures, making sure the children are sent to appropriate accommodation as soon as possible, and providing referrals for psychiatric treatments.

The adults are transferred from the Center for Foreigners to the asylum home in a matter of days, weeks, or months; once there, they undergo a full medical checkup and are isolated from other residents until they have passed their first interview. ${ }^{19}$ The government is obliged to provide an official interpreter during all formal procedures. Only after the completion of the first interview does the person obtain the right to live in the main building of the asylum home with other residents and await the second interview as part of the process of the application for international protection. Most people who wait to obtain asylum protection in Slovenia live in the asylum home because few possess sufficient economic means, and a local social network, to find housing outside it. Those who are waiting for international protection have the right to be fed (though they claim the portions are meager for adults); clothed using secondhand donated garments; and to receive 18 Euros of pocket money per month, which they use primarily for

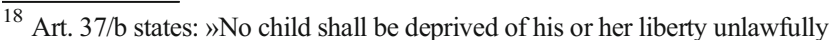
or arbitrarily. The arrest, detention or imprisonment of a child shall be in conformity with the law and shall be used only as a measure of last resort and for the shortest appropriate period of time.«

${ }^{19}$ Interviews are not scheduled during weekends. The waiting period may also be prolonged when there are no interpreters.
} 
transportation. The asylum home is located at the outskirts of Ljubljana, and to stay out overnight, one needs a special permit.

According to social workers, obtaining international protection is time-consuming and tiresome; good treatment would entail more emotional support from social workers and a shorter waiting period because the people are exhausted and disoriented after a long journey and are not properly informed about the process of the interviews. ${ }^{20}$ Refugees who came to asylum homes in Southeastern European countries were in despair because almost everyone wanted to continue the journey deeper into the West; when they were caught, they were filled with a sense of failure. The second interview is an in-depth inquiry conducted by the officers of the Ministry of the Interior, and it takes several hours to complete. The topics discussed are the histories of war, deaths, imprisonments, torture, destruction of the personal belongings, and other traumatic events as well as the person's departure from his or her home country and the journey to Europe. The interview procedure for unaccompanied children is the same as for adults, which is alarming. This interview determines whether the person receives refugee status, limited time subsidiary protection, or a temporary suspension of deportation and the decision is due, according to Slovenian legislation, within 6 months of the second interview. If the person's request is refused, deportation to his or her home country will follow. The different statuses fragment the people's lives, expectations, and human dignity, and raise the question of the objectivity/arbitrariness of such decisions.

A closer look at the procedure regarding unaccompanied children in Slovenia offers yet another insight into a fragmented and bureaucratized process that is a far cry from meeting international principles on the rights of children. Within a short period, the child exchanges three different protectors of his or her rights, appointed by a state-run center of social work. After arrival into the country a legal guardian for specific circumstances is appointed; during the process of obtaining the international protection, a legal guardian is assigned to the child (Decree on the implementation of the statutory representation of unaccompanied minors and the method of ensuring adequate accommodation, care and treatment of unaccompanied minors outside the Asylum Centre or a branch thereof 2017); and finally, as the child receives asylum protection, a guardian (skrbnik) is assigned. Legal guardians (who are rarely social workers), are responsible for the protection of the child's rights by organizing a basic institutional network for the child (e.g., school enrollment and additional learning help, doctor check-ups, and additional documents that are needed); at the same time, the developing of emotional relationships with the children or getting personally involved is undesirable.

\footnotetext{
$\overline{{ }^{20}}$ We are indebted to NGOs Slovenian Philanthropy (Slovenska filantropija) and Relation (Odnos), and to social workers Emy Poljanšek and Lea Rojec, legal guardians for unaccompanied children, who provided us with details and indepth understanding of social work practice in the detention and asylum facilities.
}

Many social workers doubt that such a procedure is in the best interest of the child, considering the discontinuities and disruptions that occur during the processes of trust building, belonging, long-term support, and representation and advocacy. Apparently, the government officials do not share this concern.

Children who are granted international protection but have no relatives live in boarding schools in two smaller towns in the country in Postojna and Logatec (in 2015 and 2016, they were placed in the crisis centers for children and young people). Only a few are placed in foster care; although small in numbers, some foster parents are an example of an excellent welfare practice for children (engaged foster parents who find the way to manage the system, emotional support, educational achievements of the children, extended intercultural network of a child, extra support in the school, and everyday life). Several NGOs organize small-scale activities funded by the state such as information support, language skill training, women-only groups, support for mothers, and help for children with school activities. Most of these activities are short term because people go and new ones arrive. Frustration resulting from discontinuities, loss, and public xenophobia are experienced not only by the refugees but also by the social workers who support them. The accommodation for children is still unstable and in the previous years, one of the more problematic practices was re-placement of children who had already been enrolled in school and had formed a network in one part of the country, to another part of the country, severely affecting continuity and the already developed social network. Some social workers report also the issue of safety for girls and younger boys who live in the boarding schools together with older young people. The government still lacks a systematic approach to the accommodation of unaccompanied minors.

During the long wait for a status decision, many people disappear; social workers who do work as legal guardians of unaccompanied children report their own feelings of loss and frustration because they often see the child only once or twice before the child disappears. Children face the dangers of human trafficking and everyday abuse.

After the closure of the Balkan Humanitarian Corridor, several human rights initiatives which are carried out by different volunteers including social workers in different Southeast European countries support people on the move. In Croatia, an international NGO "Are you Syrious" partially funded by the local municipality and the Ministry of social policy and youth provide daily support and the integration center to refugees and asylum seekers; the organization facilitates access to education, housing, and employment and provide daily news from the field to the people to the refugees (Mindoljević Novak 2017, Voluntary Center Zagreb n.d.). In Serbia, the place called Miksalište (Refugee Aid Miksališče ${ }^{21}$ ) was opened in 2016 to collect food, sanitary equipment, and clothes for the people on

\footnotetext{
${ }^{21}$ Meaning »a mixing point $\ll$.
} 
the move (Kurjački 2016). Volunteers from all over the world work there. Social workers are not in the front line in any of the countries of Southeast Europe. In Bosnia and Herzegovina, similarly than in other countries, the representative of the Red Cross told the journalists that they await the instructions from the ministry of interior, and then they can act. The direct support on the streets is given by the volunteers and people who donate money, clothes, and other humanitarian aid (Hayat TV BIH News 2018).

\section{Conclusion}

Anti-immigrant sentiment in Southeastern Europe did not come as a surprise; it grew from the fertile ground of postsocialist primordialist ideologies, and the massive economic impoverishment of people in a region steadily turning into a periphery mined for cheap labor by the core countries of the West (Rajgelj 2012). The interconnectedness of racism, homophobia, neopatriarchy, and anti-refugee sentiment is in itself a very pressing human rights issue. Refugees and migrant people remain dehumanized while most social workers turn their backs on their difficult situation. The existential worries of impoverished people in the region, their increasingly precarious work conditions, and the atmosphere of economic insecurity are used by the right-wing parties and religious fundamentalists to spread the discourse of fear, endangerment, and hatred.

In most countries in the region, migration crises are repeatedly used for intraparty politics. In Macedonia and Slovenia, for example, right-wing parties claim that NGOs working with refugees want to destabilize the state; similar propaganda was part and parcel of the 2018 Orbán election campaign depicting George Soros as cutting down the razor wires at the Hungarian border. In some countries, migration issues are even used geostrategically: in Macedonia, an EU member state candidate, hopes were high for a reward from the EU-in return for hermetically closing its southern border (Beznec et al. 2016, p. 27).

Ife (2010) reminds us that "human rights cannot be realized in isolation" (p. 158), neither in detention centers and isolated asylum homes, in the situations of social distance or razorwire encircled countries, nor in a country within. Human rights are everybody's issue and an international responsibility of all countries. Urgently, it must become everybody's issue that the populist leaders and religious fundamentalists systematically prevent human diversity and pluralism from becoming part of everyday, universal human rights. With economic and social conflicts stepped up because of equally uncompromising, fundamentalist neoliberalism, it seems that the momentum for democratic coexistence, including the people on the move, has been lost. Narratives from the field confirm that hatred, framed as coercive care, is widely normalized.
What then can social work do in the present context of Southeastern Europe? For one, it would probably help if social work broke the chains of non-political "helping families and children" and "empowering everybody," and acknowledge the historic power inequalities and problems of diversity. Second, it would help if social work could break away from its dependency on the state, its instructions and top-down social programs that "tell" the social workers "what needs be done." It would be of crucial importance that social workers achieve an autonomous professional standing and a degree of self-determination. These are the preconditions for active advocacy of the rights of all people, the refugees included.

Open Access This article is distributed under the terms of the Creative Commons Attribution 4.0 International License (http:// creativecommons.org/licenses/by/4.0/), which permits unrestricted use, distribution, and reproduction in any medium, provided you give appropriate credit to the original author(s) and the source, provide a link to the Creative Commons license, and indicate if changes were made.

Publisher's Note Springer Nature remains neutral with regard to jurisdictional claims in published maps and institutional affiliations.

\section{References}

Alvarez, M. (2017). Contingent no more, The Baffler, 3. maj. http:// thebaffler.com/the-poverty-of-theory/contingent-no-more (5. 9. 2017). Accessed 16 Nov 2018.

Amin, S. (2009). Eurocentrism. Modernity, religion, and democracy: a critique of eurocentrism and culturalism. New York, NY: Monthly Review Press.

Anderson, B. (1995). Imagined communities. London: Verso.

Balibar, É. (2004). We, the people of Europe? Reflection on transnational citizenship. Princeton, N.Y.: Princeton University Press.

Balibar, É. (2015). Europe and the refugees: a demographic enlargement. Retrieved from https://www.opendemocracy.net/can-europe-makeit/etienne-balibar/europe-and-refugees-demographic-enlargement. Accessed 16 Nov 2018.

Banich, S., Brnardić, S., Hameršak, M., Kekuš, S., Marčetić, I., Piškor, M., \& Sindičić, M. (25 March 2016). Report on systemic human rights violations by the Croatian authorities in Slavonski Brod. Retrieved from http://moving-europe.org/report-on-systemichuman-rights-violations-by-the-croatian-authorities-in-the-closedparts-of-the-winter-reception-and-transit-centre-in-slavonski-brod/. Accessed 16 Nov 2018.

Belgrade Center for Human Rights. (2017). Right to asylum in the Republic of Serbia: periodic report for July-October 2017. Retrieved from http://azil.rs/en/wp-content/uploads/2017/11/ Periodic-report-July-October-2017-asylum.pdf.

Berardi, F. (2017). Resignation letter from Franco "Bifo" Berardi to DiEM25. Retrieved from https://www.opendemocracy.net/caneurope-make-it/yanis-varoufakis-franco-berardi/resignation-letterfrom-franco-bifo-berardi-to-ya. Accessed 16 Nov 2018.

Beznec, B., Speer, M., \& Stojić Mitrović, M. (2016). Governing the Balkan route: Macedonia, Serbia and the European border regime. Retrieved from http://bordermonitoring.eu/berichte/2017mazedonien-serbien/. Accessed 16 Nov 2018. 
Boček, T. (2017). Report of the fact-finding mission by Ambassador Tomáš Boček, special representative of the secretary general on migration and refugees to Serbia and two transit zones in Hungary. Retrieved from https://search.coe.int/cm/Pages/result details.aspx?ObjectId=090000168075e9b2. Accessed 23 April 2018.

Bradol, J. H. (2004). The sacrificial international order and humanitarian action. In F. Weissman (Ed.), In the shadow of "just wars" violence, politics and humanitarian action. London: Hurst.

Constitution of the Republic of Bulgaria. (1991). Official Gazette, no. 56/ 1991, 85/2003, 18/2005, 27/2006, 78/2006, 12/2007, 100/2015. https:/www.constituteproject.org/constitution/Bulgaria_2015.pdf? lang=en. Accessed 16 Nov 2018.

Constitution of the Republic of Croatia. (1990). Official Gazette, no. 56/ 90, 135/97, 8/98, 113/00, 124/00, 28/01, 41/01, 55/01, 76/10, 85/10, 05/14. https://www.zakon.hr/z/94/Ustav-Republike-Hrvatske. Accessed 16 Nov 2018.

Constitution of the Republic of Serbia. (2006). Official Gazette, no. 98/ 2006. http://www.wipo.int/wipolex/en/text.jsp?file_id=191258. Accessed 16 Nov 2018.

Constitution of the Republic of Slovenia. (1991). Official Gazette no. 33/ 11991, 42/1997, 66/2000, 24/2003, 69/2004, 68/2006, 47/2013, 75/ 2016. http://pisrs.si/Pis.web/pregledPredpisa?id=USTA1\#.

Decree on the implementation of the statutory representation of unaccompanied minors and the method of ensuring adequate accommodation, care and treatment of unaccompanied minors outside the Asylum Centre or a branch thereof. (2017). Official Gazette of the Republic of Slovenia, no. 35/2017. Retrieved from http://www.pisrs. si/Pis.web/pregledPredpisa?id=PRAV12671.

Donko, F. (2018). The dossier of the FSD: does the Faculty of Social Work play with the lives of their female students? NovaTV. Retrieved from http://nova24tv.si/slovenija/politika/dosje-fsd-sefakulteta-za-socialno-delo-poigrava-z-zivljenji-svojih-studentk/. Accessed 16 Nov 2018.

EU Monitoring and Advocacy Programme. (2007). Equal access to quality education for Roma, Vol. 1 \& 2. [Monitoring reports.] Budapest, Hungary: Open Society Institute.

Feldman, A. (2015). Archives of insensible: of war, photopolitics and dead memory. Chicago, IL: University of Chicago Press.

Foreigners Act. (2017). Official Gazette of the Republic of Slovenia, no. 50/2011 and further. Retrieved from http://www.pisrs.si/Pis.web/ pregledPredpisa?id=ZAKO5761.

Fraser, N. (2007). Mapping the feminist imagination: From redistribution to recognition to representation. In J. Browne (Ed.), The future of gender (pp. 17-34). Cambridge: Cambridge University Press.

Geertz, C. (1963). The integrative revolution: primordial sentiments and civil politics in the new states. In C. Geertz (Ed.), Old societies and new states: The quest for modernity in Asia and Africa. New York: Free Press.

Gellner, E. (1983). Nations and nationalism. Oxford: Blackwell.

Gessen, M. (2018). Taking children from their parents is a form of state terror. The New Yorker. Retrieved from https://www.newyorker. $\mathrm{com} /$ news/our-columnists/taking-children-from-their-parents-is-aform-of-state-terror. Accessed 16 Nov 2018.

Gregorc, E. (2018). The new left harbors a new ideology that is not less anti-Christian, but more. Domovina. Retrieved from https://www. domovina.je/dr-anton-stres-pri-novi-levici-za-novo-ideologijo-kini-nic-manj-antikrscanska-ampak-celo-bolj-1-del-intervjuja/.

Hathaway, J. C. (2016). A global solution to a global refugee crisis. Retrieved from http://verfassungsblog.de/a-global-solution-to-aglobal-refugee-crises/. Accessed 16 Nov 2018.

Hayat TV BIH News. (2018). Novi val izbjeglica u BIH, pomoč pružaju volonter i građani. 23. April. Retrieved from https://www.youtube. com/watch?v=DfL1qzn_7nk. Accessed 16 Nov 2018.
Hessle, S., \& Zaviršek, D. (Eds.). (2005). Sustainable development in social work: the case of a regional network in the Balkans. Stockholm: Stockholm University.

Hodžić, A., \& Štulhofer, A. (2017). Embryo, teddy bear-centaur and the constitution: mobilizations against "gender ideology" and sexual permissiveness in Croatia. In R. Kuhar \& D. Paternotte (Eds.), Anti-gender campaigns in Europe: Mobilizing against equality (pp. 59-77). Lanham: Rowman \& Littlefield.

HRW Croatia. (2017). Asylum seekers forced back to Serbia. Retrieved from https://www.hrw.org/news/2017/01/20/croatia-asylumseekers-forced-back-serbia. Accessed 16 Nov 2018.

HRW Serbia. (2015). Police abusing migrants, asylum seekers. Retrieved from https://www.hrw.org/news/2015/04/15/serbia-police-abusingmigrants-asylum-seekers. Accessed 16 Nov 2018.

HRW Serbia/Kosovo. (2017). Human rights watch report. Retrieved from https://www.hrw.org/europe/central-asia/serbia/kosovo. Accessed 16 Nov 2018.

Humljan Urh, Š. (2014). Everyone is blaming us! Conceptualising current anti-Roma racism in Europe and its necessary implications for antiracist social work. Critical and Radical Social Work, 2(1), 59-76.

Ife, J. (2010). Human rights from below. Melbourne: Cambridge University Press.

ILGA-Europe. (2015). Annual review of the human rights situation of lesbian, gay, bisexual, trans and intersex people in Europe. Retrieved from https://www.ilga-europe.org/sites/default/files/ Attachments/01_full_annual_review_updated.pdf. Accessed 16 Nov 2018.

Knight, K. (2017). Sofia LGBT pride should showcase a tolerant Bulgaria. Retrieved from https://www.hrw.org/news/2017/06/05/ sofia-lgbt-pride-should-showcase-tolerant-bulgaria. Accessed 16 Nov 2018.

Košir, I. (2018). "Our girls.” Who's afraid of the students from Faculty of Social Work? [»Naša dekleta«; Kdo se boji študentk Fakultete za socialno delo?], Mladina. Retrieved from http://www.mladina.si/ 184730/nasa-dekleta/. Accessed 16 Nov 2018.

Kurjački, N. (2016). Ponovo radi Miksalište, kutak za izbeglice u Beogradu. TV N1, 31. May, Retrieved from http://rs.n1info.com/ a165030/Vesti/Vesti/Miksaliste-na-novoj-adresi.html. Accessed 16 Nov 2018.

Law, I. (2012). Red racism. Racism in Communist and post-Communist context. Hampshire: Palgrave, MacMillan.

Lipovec Čebron, U., \& Zorn, J. (2016). The Authonomy and the control of migration in the European tampon zones [Avtonomija in nadzor migracij v evropskih tamponskih conah]. Dve domovini, 43, 61-75.

Matić, Ž. (2018). The Croation police brutally against migrants [Hrvaška policija brutalno proti migrantom]. Delo, 18. August. Retrieved from https://www.delo.si/novice/svet/hrvaska-policija-brutalnoproti-migrantom-82559.html. Accessed 16 Nov 2018.

Mbembe, A. (2017). Politik der Feindschaft. Berlin: Suhrkamp.

Mindoljević Novak, L. (2017). The place for donations to are you Syrious to help migrants [Prostor za donacije are you Syrious za pomoć migrantima]. Jutranji list, 5. July. Retrieved from https://www. jutarnji.hr/domidizajn/interijeri/prostor-za-donacije-are-yousyrious-za-pomoc-migrantima/6313153/. Accessed 16 Nov 2018.

Mladjenović, L. (2001). Notes of a feminist lesbian during wartime. The Europrean Journal of Women's Studies, 8(3), 381-391.

Muižnieks, N. (2015). Report of the Commissioner for Human Rights of the Council of Europe following his visit to Serbia from 16 to 20 March 2015. Retrieved from https://rm.coe.int/report-on-the-visitto-slovenia-from-20-to-23-march-2017-by-nils-muizn/ 1680730405. Accessed 16 Nov 2018.

Muižnieks, N. (2017). Report of the Commissioner for Human Rights of the Council of Europe following his visit to Slovenia from 20 to 23 March 2017. Retrieved from https://rm.coe.int/report-on-the-visitto-slovenia-from-20-to-23-march-2017-by-nils-muizn/ 1680730405. Accessed 16 Nov 2018. 
Murat, B. (2009). Reconsidering primordialism: An alternative approach to the study of ethnicity. Ethnic and Racial Studies, 32(9), 1-20.

Rajgelj, B. (2012). The effects of labour, citizenship and family status on the unequal treatment in health insurance. Slovenian Journal of Public Health, 51(1), 43-52.

RFE. (2017). Serbia's gay prime minister joins pride parade in Belgrade. Retrieved from https://www.rferl.org/a/serbia-pm-brnabic-to-joinbelgrade-gay-pride-parade/28740208.html. Accessed 20 April 2018.

Schwenken, H. (2018). Global migration. Hamburg: Junius.

Simo, A. (2001). Violence stops Yugoslavia gay pride. Retrieved from http://www.thegully.com/essays/gaymundo/010705gay_ yugoslavia.html. Accessed 16 Nov 2018.

Slootmaeckers, K., Touquet, H., \& Vermeersch, P. (2016). The EU enlargement and gay politics. The impact of eastern enlargement on rights, activism and prejudice. London: Palgrave Macmillan.

Stoyanova Packova, P. (2016). The migration waves and the public opinion in Bulgaria. Annales Universitatis Mariae Curie-SkLodowska Lublin., 23(1), 121-129.

Šmi, I. (2012). Unable to heal: debate on the national self in postsocialist Slovenia. In R. Hudson \& G. Bowman (Eds.), After Yugoslavia : identities and politics within the successor states (pp. 153-181). New York: Palgrave Macmillan.

Šumi, I., \& Janko Spreizer, A. (2011). That which soils the nation's body: discriminatory discourse of Slovenian academics on the Romany, foreigners and women. Anthropological Notebooks, 17(3), 101-121.

UN High Commissioner for Refugees. (2012). Serbia as a country of asylum. Retrieved from http://www.unhcr.rs/media/ UNHCRSerbiaCountryofAsylumScreen.pdf. Accessed 16 Nov 2018.
UN High Commissioner for Refugees. (2016). Right to asylum In the Republic of Serbia. Retrieved from http:/www.asylumineurope. $\mathrm{org} / \mathrm{sites} / \mathrm{default} /$ files/resources/right-to-asylum-in-the-republic-ofserbia-2016-2.pdf. Accessed 16 Nov 2018.

Urh, Š. (2011). Ethnic sensitivity: a challenge for social work. International Social Work, 54(4), 471-484.

Voluntary Center Zagreb. (n.d.). [Volonterski centar Zagreb] Are You Syrious. Retrived from http://www.vcz.hr/ and http://www.vcz.hr/ partneri/organizatori-volontiranja/organizator-1691/. Accessed 16 Nov 2018.

Walsh, J. (2018). Rep. Pramila Jayapal - 'they could hear their children screaming for them in the next room'. The Nation. Retrieved from https://www.thenation.com/article/rep-pramila-jayapal-hearchildren-screaming-next-room/. Accessed 16 Nov 2018.

Zaviršek, D. (2001). Lost in public care: the ethnic rights of the ethnic minority children. In L. Dominelli, H. Soydan, \& W. Lorenz (Eds.), Beyond racial divides: ethnicities in social work practice. Aldershot: Ashgate.

Zaviršek, D. (2017). The humanitarian crisis of migration versus the crisis of humanitarianism: current dimensions and challenges for social work practice. Social Work Education, 36(3), 231-244.

Zaviršek, D. (2018). Coersive care . [Skrb kot nasilje]. Ljubljana, Slovenia: $/ c f^{*}$.

Zorn, J. (2005). Ethnic citizenship in the Slovenian state. Citizenship Studies, 9(2), 135-152.

Zorn, J. (2009). A case for Slovene nationalism: Initial citizenship rules and the erasure. Nations and Nationalism, 15(29), 280-298. 